\author{
Д. С. Носівець, В. Й. Мамчур, В. І. Опришко
}

\title{
Зміни вмісту металопротеїназ сироватки крові щурів під впливом нестероїдних протизапальних засобів і парацетамолу на фоні експериментального остеоартрозу та гіпотиреозу
}

\author{
Державий заклад «Дніпропетровська медична академія \\ Міністерства охорони здоров'я України», м. Дніпро
}

Ключові слова: остеоартроз, гіпотиреоз, фармакотерапія, біохімічні маркери, матриксні металопротеїнази, нестероїдні протизапальні засоби

Одна з проблем лікування коморбідних станів пов'язана 3 визначенням факторів, які могли б передбачити ефективність лікування остеоартрозу (OA) на фоні гіпотиреозу. Натепер відомо, що гіпофункція щитоподібної залози (ЩЗ) призводить до метаболічних порушень, які негативно впливають на стан кісткової та хрящової тканини, зумовлюючи розвиток ОА $[1,2]$.

Проявами ОА вважають патологічні зміни з боку хрящової та кісткової тканин і синовіальної оболонки, яка реагує на захворювання запальною реакцією. Хоча нестероїдні протизапальні засоби (НПЗ3) ефективні для зменшення болю та запалення в пацієнтів з ОА, дотепер не зрозуміло, якою мірою ці препарати можуть впливати на патологічний процес у суглобі й, отже, на протікання ОА, особливо на тлі функціональної недостатності Щ3 [3, 4].

Особливість лікування ОА на фоні гіпотиреозу пов'язана 3 призначенням базової замісної гормональної терапії та НПЗЗ і парацетамолу, проте питання впливу НПЗ3 на кісткову тканину та взаємодія даних препаратів за коморбідної патології, на наш погляд, досліджені недостатньо [3-5].

Відомо, що матриксні металопротеїнази (ММП) відносяться до позаклітинних цинкових протеїназ, які здатні специфічно гідролізувати основні білки

(c) Колектив авторів, 2020 позаклітинного матриксу. За специфічністю ММП можна розділити на колагенази (ММП-1, -8 і -13), желатинази (ММП-2 і -9) і стромелізини (ММП-3 і -10). Раніше вважалося, що головна роль у деструкції матриксу належить ММП-1, потім була встановлена важлива роль ММП-13 і ММП-3. ММП-3 або стромелізин-1 каталізує деградацію багатьох компонентів сполучної тканини, включаючи протеоглікани та колаген II типу. ММП-3 активує проформи ММП-1, 7, 8 і 13, і ця активація е ключовою за патології хряща. Експресія ММП-3 відображає активність захворювання та процес пошкодження суглоба за умов ОА та ревматоїдного артриту. Отримано дані, що ММП-3 відіграє важливу роль у процесах тканинного ремоделювання, зокрема, у разі ОА. Однак за деякими даними у разі ОА рівень експресії гена ММП-3 у хрящовій тканині знижений [6-8].

ММП-9 також відома як желатиназа В, секретується як профермент. Субстрати для ММП-9 включають денатурований колаген I типу, нативні колагени типів IV, V, VII, X і XI, фібриноген, вітронектин, IL-1 й ентактин. Базальні рівні ММП-9 є зазвичай низькими, їі експресія може індукуватися різними цитокінами/хемокінами, включаючи TNF- $\alpha$, і головним чином секретується запальними клітинами [7, 9]. ММП-9 бере участь у процесах запалення, ремоделювання тканин і репарації, мобілізації матрикс-пов'язаних факторів росту та процесингу цитокінів [6].

ММП-13 відома як колагеназа-3, має широку специфічність і руйнує колаген 
II типу. Сьогодні збільшуеться кількість досліджень, які підтверджують важливу роль ММП-13 у розвитку ОА та ревматоїдного артриту [10-12]. ММП-13 бере участь у загоєнні ран у багатьох тканинах, включаючи кістку, райдужну оболонку ока та суглобову тканину [6].

У разі захворювань опорно-рухового апарату ММП утворюють у зоні резорбції кістки та хряща великі комплекси, що складаються з двох С-телопептидів молекул колагену I і II типу. Ці комплекси потрапляють у кровоток і потім виводяться з сечею, однак їхня структура не є стабільною, і вони руйнуються під дією катепсину $\mathrm{K}$, а також протеолітичних ферментів у судинному руслі, у результаті чого в кровотоці циркулюють різні фрагменти С-телопептиду. У разі ОА спостерігається підвищення рівня багатьох ММП у сироватці крові, тканинах і синовіальній рідині $[6,8,13,14]$.

Мета дослідження - вивчити зміни рівня ММП 3, 9 і 13 під впливом НПЗ3 і парацетамолу на фоні експериментальних еквівалентів ОА та гіпотиреозу.

Матеріали та методи. Дослідження проведені на 75 білих нелінійних щурах масою 200-250 г, яких утримували в стандартних умовах віварію ДЗ «ДМА MO3 України». Експериментальні дослідження виконані відповідно до «Загальних етичних принципів експериментів на тваринах" (Україна, 2001 р.) і положень «Європейської конвенції про захист хребетних тварин, які використовуються для експериментальних та інших наукових цілей» (Страсбург, 1986 р.). Протокол дослідження затверджено етичною комісією ДЗ «ДМА МОЗ України» (протокол від 18.01.2015 № 1).

Експериментальний остеоартроз (EOA) відтворювали на початку дослідження шляхом одноразового внутрішньосуглобового введення 0,1 мл розчину монойодоцтової кислоти (реактив Iodoacetic acid $\geq 98,0 \%$ T, № I4386, виробник Sigma-Aldrich Chemie GmbH, Німеччина) у колінний суглоб, який готували з розрахунку 3 мг реактиву на 50 мкл стерильного фізіологічного розчину $[15,16]$, та з цієї самої доби розпо- чинали моделювання експериментального гіпотиреозу (ЕГ) шляхом ентерального введення 0,02 \% розчину карбімазолу (препарат «Еспа-карб», виробництва Еспарма ГмбХ, Німеччина; таблетки по 5 або 10 мг), який готували 3 розрахунку 5 мг на 250 мл фізіологічного розчину та давали з питним раціоном тварин упродовж 6 тижнів [17].

На 42 добу експерименту тварин вибірково розділили на 14 дослідних груп по 5 щурів у кожній групі $(\mathrm{n}=5)$ : I група - щури з ЕГ + EОА без лікування; II група - щури, які отримували L-тироксин (T) (виробник «BerlinChemie», Німеччина) у дозі 1,5 мкг/кг (внутрішньошлунково (в/ш); III група диклофенак натрію (Д) (виробник ПАТ «Хімфармзавод «Червона зірка», Україна) у дозі 10 мг/кг (в/ш); IV група $\mathrm{T}+$ Д у відповідних дозах в/ш; V група - ібупрофен (I) (виробник ПАТ НВЦ «Борщагівський хіміко-фармацевтичний завод", Україна) у дозі 5 мг/кг (в/ш); VI група - T + I у відповідних дозах в/ш; VII група - мелоксикам (Мел) (виробник ПрАТ «Лекхім-Харків», Україна) у дозі 10 мг/кг (в/ш); VIII група $-\mathrm{T}+$ Мел у відповідних дозах в/ш; IX група - парацетамол (П) (виробник ПАТ «Галичфарм», Україна) у дозі 150 мг/кг (в/ш); Х група - T + П у відповідних дозах в/ш; XI група німесулід (Н) (виробник ПрАТ «Лекхім-Харків», Україна) у дозі $80 \mathrm{мг/кг}$ (в/ш); XII група - T + Н у відповідних дозах в/ш; XIII група - целекоксиб (Ц) (препарат «Флогоксиб-Здоров'я», виробник ФК «Здоров'я», Україна) у дозі 50 мг/кг (в/ш); XIV група - T + Ц у відповідних дозах в/ш. Вибір препаратів заснований на вимогах настанов для первинної медичної допомоги 3 лікування ОА та гіпотиреозу (http:// guidelines.moz.gov.ua).

Введення препаратів здійснювали щоденно з 42 доби експерименту впродовж 5 діб у дозах і режимах, наведених вище. Для отримання однорідної суспензії для в/ш введення таблетованих форм використовували розчин Твіну-80 (Полісорбат 80, Україна).

Кількісний рівень ММП 3 (ММП-3), 9 (ММП-9) і 13 (ММП-13) сироватки крові визначали методом конкурентного 
імуноферментного аналізу (ІФА) in vitro двічі (на 42 і 47 добу експерименту) з використанням імуноферментних тест-систем Elabscience Biotechnology Inc. (США), «MBS» (США) та Bender MedSystems GmbH (Німеччина) згідно з методикою виробника, яка була описана в технічній документації. Чутливість визначення дорівнювала 0,1 нг/ мл. За референтний рівень ММП прийняті значення, отримані в групі інтактних щурів (n = 5) (таблиця). Зразки крові отримували 3 хвостової вени щурів шляхом її пункції за допомогою вакуумної системи на 42 і 47 добу експерименту.

Тривалість введення препаратів складала 5 діб. На 47 добу експерименту всіх тварин після забору крові виводили 3 дослідження шляхом декапітації під загальним знеболенням $[18,19]$.

Статистичну обробку даних проводили 3 використанням пакета програм STATISTICA 6.1 (StatSoftInc., серійний номер AGAR909E415822FA) та включали розрахунки середніх арифметичних значень $(\mathrm{M})$ та їхніх похибок $( \pm \mathrm{m})$. Вірогідність різниці середніх арифметичних (p) значень показників проводили за допомогою непараметричного U-критерію Манна-Уїтні. Встановлення вірогідності внутрішньогрупових і міжгрупових відмінностей проводили за допомогою параметричного $\mathrm{t}$-критерію Стьюдента та методу однофакторного дисперсійного аналізу (ANOVA). Відмінності вважали статистично достовірними в разі $\mathrm{p} \leq 0,05$. Перед застосуванням параметричних критеріїв проводили перевірку гіпотези про нормальний закон розподілу випадкових величин [20].

Результати та їх обговорення. Аналіз отриманих результатів показав, що зміни рівня ММП-3, ММП-9 та ММП13 у сироватці крові щурів під впливом НПЗ3 і П відбуваються неоднаково (таблиця).

Так, на 42 добу в усіх експериментальних групах спостерігали достовірне ( $\mathrm{p} \leq$ 0,05) підвищення рівня ММП-3, ММП-9 і ММП-13 порівняно 3 референтними значеннями інтактної групи щурів (ІЩ), що відображає розвиток патологічних змін за умов моделювання ОА та гіпотиреозу. На 47 добу екс- перименту в I групі спостерігали підвищення рівня ММП-3, ММП-9 і ММП-13 на $15,7 \%, 36,0 \%$ та 7,0 \% відповідно порівняно з 42 добою, що свідчить про наростання патологічних змін за умов відсутності лікування. Проте достовірні значення при порівнянні рівнів ММП на 42 та 47 добу експерименту в I групі спостерігали лише за вмістом ММП-9 (таблиця).

Під впливом базової замісної терапії T (II група) спостерігали достовірне $(\mathrm{p}=0,04)$ зниження рівнів досліджуваних ММП порівняно з показниками I групи. Так, за рівнем ММП-3, ММП-9 та ММП-13 визначено зниження даних показників у II групі на $12,04 \% ; 23,46 \%$ та 9,32\% відповідно порівняно з I групою, що свідчить про доцільність призначення $\mathrm{T}$ за ОА та гіпотиреозу та відображає вплив Т на рівень досліджуваних ММП (таблиця).

Як видно з даних таблиці, у разі порівняння отриманих результатів 3 I групою (патологія без лікування) встановлено достовірне $(\mathrm{p} \leq 0,05)$ різного ступеня зменшення рівнів ММП під впливом НПЗЗ, П та Т за умов коморбідної патології, що свідчить про доцільність застосування зазначених препаратів.

Так, встановлено, що в III групі 3 використанням Д на 47 добу експерименту рівень ММП-3 достовірно ( $\leq$ $0,05)$ зменшувався на $43,8 \%$, ММП-9 на 60,56 \%, ММП-13 - на 35,04 \% порівняно з I групою (таблиця).

Аналіз результатів у IV групі з сумісним застосуванням Д та T, встановив достовірне $(\mathrm{p} \leq 0,05)$ зниження ММП-3, ММП-9 та ММП-13 на 47,64 \%, 64,57 \% і $38,64 \%$ відповідно (таблиця).

Найменший вплив на рівень ММП встановлений у IX i X групах з використанням П та П із Т. Так, за рівнем ММП-3, ММП-9 та ММП-13 у IX і X групах показники зменшились на $16,23 \%, 23,13 \%, 10,91 \%$ та $17,28 \%$, $31,15 \%, 12,45 \%(\mathrm{p} \leq 0,05)$ відповідно порівняно з показниками I групи, проте достовірних міжгрупових відмінностей не встановлено (таблиця).

Загалом, 3 огляду на отримані результати, за ступенем впливу на рівень ММП сироватки крові щурів 
Таблиця

Рівень матриксних металопротеїназ 3, 9 та 13 у сироватиі крові иурів за введення нестероїдних протизапальних засобів і парацеталолу на фоні експерилентального остеоартрозу та гіпотиреозу $(M \pm m)$

\begin{tabular}{|c|c|c|c|c|c|c|}
\hline \multirow{2}{*}{$\begin{array}{l}\text { Експериментальна } \\
\text { група }\end{array}$} & \multicolumn{3}{|c|}{$\begin{array}{c}\text { Рівень металопротеїназ } \\
\text { на } 42 \text { добу, нг/мл }\end{array}$} & \multicolumn{3}{|c|}{$\begin{array}{c}\text { Рівень металопротеїназ } \\
\text { на } 47 \text { добу, нг/мл }\end{array}$} \\
\hline & ММП-3 & ММП-9 & ММП-13 & ММП-3 & ММП-9 & ММП-13 \\
\hline Інтактні щури (n=5) & $\begin{array}{c}0,50 \pm \\
0,16\end{array}$ & $\begin{array}{c}0,22 \pm \\
0,13\end{array}$ & $\begin{array}{c}0,78 \pm \\
0,19\end{array}$ & $\begin{array}{c}0,48 \pm \\
0,15\end{array}$ & $\begin{array}{c}0,30 \pm \\
0,16\end{array}$ & $\begin{array}{c}0,70 \pm \\
0,22\end{array}$ \\
\hline $\begin{array}{l}\text { І група. Гіпотиреоз + } \\
\text { остеоартроз (патологія } \\
\text { без лікування) (n= 5) }\end{array}$ & $\begin{array}{c}49,52 \pm \\
6,29 *\end{array}$ & $\begin{array}{l}22,0 \pm \\
4,36^{\star}\end{array}$ & $\begin{array}{l}72,80 \pm \\
3,63^{\star}\end{array}$ & $\begin{array}{c}57,30 \pm \\
4,37^{\star}\end{array}$ & $\begin{array}{c}29,92 \pm \\
2,29^{\star}\end{array}$ & $\begin{array}{l}77,90 \pm \\
3,44^{\star}\end{array}$ \\
\hline $\begin{array}{l}\text { II група. L-тироксин } \\
\text { 1,5 мкг/кг }(\mathrm{n}=5)\end{array}$ & $\begin{array}{l}51,74 \pm \\
6,67^{\star}\end{array}$ & $\begin{array}{c}23,80 \pm \\
3,96^{\star}\end{array}$ & $\begin{array}{l}71,28 \pm \\
3,32^{*}\end{array}$ & $\begin{array}{l}50,40 \pm \\
4,56^{\star, \star \star}\end{array}$ & $\begin{array}{l}22,90 \pm \\
3,13^{\star, \star \star}\end{array}$ & $\begin{array}{l}70,64 \pm \\
3,02^{\star, * *}\end{array}$ \\
\hline $\begin{array}{l}\text { III група. Диклофенак } \\
\text { натрію } 10 \text { мг/кг (n = 5) }\end{array}$ & $\begin{array}{c}50,52 \pm \\
5,03^{\star}\end{array}$ & $\begin{array}{l}22,60 \pm \\
3,85^{\star}\end{array}$ & $\begin{array}{l}71,40 \pm \\
4,04^{\star}\end{array}$ & $\begin{array}{l}32,20 \pm \\
3,56^{\star}, \star \star\end{array}$ & $\begin{array}{l}11,80 \pm \\
2,59^{\star, \star \star}\end{array}$ & $\begin{array}{l}50,60 \pm \\
3,05^{\star, \star \star}\end{array}$ \\
\hline $\begin{array}{l}\text { IV група. Диклофенак } \\
\text { натрію + L-тироксин } \\
(\mathrm{n}=5)\end{array}$ & $\begin{array}{l}50,0 \pm \\
5,70 *\end{array}$ & $\begin{array}{c}23,30 \pm \\
4,84^{\star}\end{array}$ & $\begin{array}{c}70,26 \pm \\
5,94^{\star}\end{array}$ & $\begin{array}{c}30,0 \pm \\
3,24^{\star, \star \star}\end{array}$ & $\begin{array}{l}10,60 \pm \\
2,51^{\star, \star \star}\end{array}$ & $\begin{array}{l}47,80 \pm \\
2,39^{\star, \star *}\end{array}$ \\
\hline $\begin{array}{l}\text { V група. Ібупрофен } \\
5 \text { мг/кг (n = 5) }\end{array}$ & $\begin{array}{c}51,20 \pm \\
5,63^{\star}\end{array}$ & $\begin{array}{c}22,40 \pm \\
4,72^{\star}\end{array}$ & $\begin{array}{c}71,20 \pm \\
5,81^{\star}\end{array}$ & $\begin{array}{l}36,80 \pm \\
3,11^{\star, \star \star}\end{array}$ & $\begin{array}{l}15,20 \pm \\
2,59^{\star}, \star \star\end{array}$ & $\begin{array}{l}56,20 \pm \\
3,70^{\star}, \star \star\end{array}$ \\
\hline $\begin{array}{l}\text { VI група. Ібупрофен + } \\
\text { L-тироксин }(\mathrm{n}=5)\end{array}$ & $\begin{array}{c}49,40 \pm \\
6,02^{*}\end{array}$ & $\begin{array}{c}22,80 \pm \\
4,21^{\star}\end{array}$ & $\begin{array}{c}72,60 \pm \\
6,19^{\star}\end{array}$ & $\begin{array}{l}34,80 \pm \\
3,03^{\star, \star *}\end{array}$ & $\begin{array}{c}14,0 \pm \\
2,92^{\star, \star \star}\end{array}$ & $\begin{array}{l}54,20 \pm \\
3,70^{\star, \star *}\end{array}$ \\
\hline $\begin{array}{l}\text { VII група. Мелоксикам } \\
10 \text { мг/кг }(n=5)\end{array}$ & $\begin{array}{c}51,60 \pm \\
7,06^{\star}\end{array}$ & $\begin{array}{c}22,20 \pm \\
3,96^{\star}\end{array}$ & $\begin{array}{c}71,80 \pm \\
6,76^{\star}\end{array}$ & $\begin{array}{l}41,20 \pm \\
2,59^{\star, \star *}\end{array}$ & $\begin{array}{l}17,60 \pm \\
2,41^{\star, \star \star}\end{array}$ & $\begin{array}{c}60,0 \pm \\
2,24^{\star, \star \star}\end{array}$ \\
\hline $\begin{array}{l}\text { VIII група. Мелоксикам + } \\
\text { L-тироксин }(n=5)\end{array}$ & $\begin{array}{c}50,20 \pm \\
6,53^{*}\end{array}$ & $\begin{array}{c}23,20 \pm \\
4,16^{\star}\end{array}$ & $\begin{array}{l}72,40 \pm \\
5,59^{\star}\end{array}$ & $\begin{array}{l}39,80 \pm \\
2,39^{\star, \star *}\end{array}$ & $\begin{array}{l}16,40 \pm \\
2,79^{\star, \star \star}\end{array}$ & $\begin{array}{c}57,0 \pm \\
2,24^{\star, \star *}\end{array}$ \\
\hline $\begin{array}{l}\text { IX група. Парацетамол } \\
150 \text { мг/кг (n= 5) }\end{array}$ & $\begin{array}{c}50,40 \pm \\
4,62^{\star}\end{array}$ & $\begin{array}{c}23,0 \pm \\
5,15^{\star}\end{array}$ & $\begin{array}{l}72,0 \pm \\
6,52^{\star}\end{array}$ & $\begin{array}{c}48,0 \pm \\
2,24^{\star, \star \star}\end{array}$ & $\begin{array}{c}23,0 \pm \\
2,65^{\star, \star \star}\end{array}$ & $\begin{array}{l}69,40 \pm \\
2,70^{\star, \star *}\end{array}$ \\
\hline $\begin{array}{l}\text { X група. Парацетамол + } \\
\text { L-тироксин }(\mathrm{n}=5)\end{array}$ & $\begin{array}{c}49,60 \pm \\
4,39^{*}\end{array}$ & $\begin{array}{c}23,10 \pm \\
4,95^{\star}\end{array}$ & $\begin{array}{c}70,60 \pm \\
4,16^{\star}\end{array}$ & $\begin{array}{l}47,40 \pm \\
2,30 *, \star \star\end{array}$ & $\begin{array}{l}20,60 \pm \\
2,88^{\star, \star \star}\end{array}$ & $\begin{array}{l}68,20 \pm \\
2,59^{\star, \star *}\end{array}$ \\
\hline $\begin{array}{l}\text { XI група. Німесулід } \\
80 \text { мг/кг (n= 5) }\end{array}$ & $\begin{array}{c}50,28 \pm \\
4,35^{\star}\end{array}$ & $\begin{array}{c}23,60 \pm \\
4,72^{\star}\end{array}$ & $\begin{array}{c}71,60 \pm \\
4,83^{\star}\end{array}$ & $\begin{array}{l}41,80 \pm \\
2,59^{\star, \star \star}\end{array}$ & $\begin{array}{c}17,0 \pm \\
2,92^{\star, \star \star}\end{array}$ & $\begin{array}{l}59,60 \pm \\
2,41^{\star, \star \star}\end{array}$ \\
\hline $\begin{array}{l}\text { XII група. Німесулід + } \\
\text { L-тироксин }(n=5)\end{array}$ & $\begin{array}{c}50,60 \pm \\
5,46^{\star}\end{array}$ & $\begin{array}{c}22,46 \pm \\
4,74^{\star}\end{array}$ & $\begin{array}{l}72,10 \pm \\
5,53^{*}\end{array}$ & $\begin{array}{l}39,60 \pm \\
2,61^{\star * *}\end{array}$ & $\begin{array}{l}16,20 \pm \\
2,39^{\star, \star \star}\end{array}$ & $\begin{array}{l}56,80 \pm \\
2,39^{*}, * *\end{array}$ \\
\hline $\begin{array}{l}\text { XIII група. Целекоксиб } \\
50 \text { мг/кг (n=5) }\end{array}$ & $\begin{array}{c}51,28 \pm \\
4,55^{\star}\end{array}$ & $\begin{array}{c}22,88 \pm \\
4,55^{\star}\end{array}$ & $\begin{array}{c}71,60 \pm \\
4,22^{\star}\end{array}$ & $\begin{array}{l}45,80 \pm \\
2,77^{\star, \star \star}\end{array}$ & $\begin{array}{l}20,40 \pm \\
2,41^{\star, \star \star}\end{array}$ & $\begin{array}{l}65,40 \pm \\
2,70^{\star * \star *}\end{array}$ \\
\hline $\begin{array}{l}\text { XIV група. Целекоксиб + } \\
\text { L-тироксин }(n=5)\end{array}$ & $\begin{array}{c}50,24 \pm \\
5,0^{\star}\end{array}$ & $\begin{array}{c}23,40 \pm \\
5,41^{\star}\end{array}$ & $\begin{array}{l}70,80 \pm \\
6,10^{\star}\end{array}$ & $\begin{array}{l}43,60 \pm \\
2,30^{\star, \star \star}\end{array}$ & $\begin{array}{l}19,20 \pm \\
2,59^{\star}, \star \star\end{array}$ & $\begin{array}{l}64,20 \pm \\
2,77^{\star * \star * *}\end{array}$ \\
\hline
\end{tabular}

Примітка. *Значення достовірні $(p \leq 0,05)$ порівняно до групи ІЩ, **значення достовірні $(p \leq 0,05)$ порівняно до I групи (патологія без лікування).

досліджені препарати можна розташувати наступним чином: Д > $\mathrm{I}>\mathrm{H}=$ Мел $>$ Ц > П, що відображає різну ефективність зазначених препаратів у тварин з моделлю ОА на фоні гіпотиреозу (таблиця).

У разі порівняння ефектів усіх досліджених НПЗЗ і П без Т та в поєднанні з $\mathrm{T}$ не відмічено статистично значущої різниці $(\mathrm{p}>0,05)$ між відповідними групами.

Отримані в нашому дослідженні результати узгоджуються 3 даними інших дослідників щодо підвищення рівня ММП за експериментальних моделей ОА на фоні дегенеративно-дистрофічного процесу в суглобі $[8,14$, 21-23]. На жаль, робіт з дослідження 
даного питання на фоні EOA та гіпотиреозу нами не знайдено.

Також відомо, що запальні цитокіни стимулюють синтез ММП, які руйнують усі компоненти позаклітинного матриксу за ОА. ММП-13 пошкоджує хондроцити та окрім колагену II типу руйнує молекули протеоглікану та агрегану. Експресія ММП-3 та ММП-9 підвищується за умов ОА, і ці ферменти руйнують неколагенові матричні компоненти суглобів. ММП-3 вважають системним маркером, який відображає локальне запалення суглоба $[24,25]$.

Таким чином, на підставі проведеного дослідження на щурах з моделлю ОА та гіпотиреозу встановлено суттєве підвищення (на два порядки) рівнів ММП у сироватці крові експериментальних тварин, особливо ММП-3 та ММП-9. Застосування всіх досліджених НПЗЗ і П призводило до значного зниження рівня цих маркерів запалення суглобів. Найменшою активністю щодо впливу на ММП характеризується П, найбільшою - Д.

\section{Висновки}

Визначення рівня ММП (ММП-3, 9, 13) дозволяє оцінити активність патологічних процесів на фоні експериментальних еквівалентів ОА та гіпотиреозу.

Базова замісна терапія L-тироксином на фоні експериментальних еквівалентів ОА та гіпотиреозу призводить до зниження рівня матриксних металопротеїназ і доцільна за умов такої коморбідної патології.

За ступенем впливу на рівень матриксних металопротеїназ досліджені препарати можна розташувати наступним чином: диклофенак натрію > ібупрофен > німесулід $=$ мелоксикам $>$ целекоксиб $>$ парацетамол.

1. Носивец Д. С. Влияние функциональной недостаточности щитовидной железы на костнохрящевую ткань. Morphologia. 2019. Т. 13, № 1. С. 47-51.

2. Graham R. W. Thyroid hormone actions in cartilage and bone. Eur Thyroid J. 2013. V. 2. P. 3-13.

3. Носивец Д. С. Влияние комбинации НПВС на течение остеоартроза при сопутствующем гипотиреозе. Проблемы эндокринной патологии. 2019. № 2 (68). С. 40-45.

4. Носівець Д. С. Можливість сумісного використання L-тироксину, диклофенаку натрію та хондроїтину сульфату при гіпотиреозі. Вісник проблем біології і медицини. 2019. Т. 1 (150), № 2. C. $172-176$.

5. Osteoarthritis year in review 2016: biomarkers (biochemical markers). A. Mobasheri, A. C. BayJensen, W. E. Spil et al. Osteoarthritis and Cartilage. 2017. V. 25. P. 199-208.

6. Ярмолинская М. И., Молотков А. С., Денисова В. М. Матриксные металлопротеиназы и ингибиторы: классификация, механизм действия. Журнал акушерства и женских болезней. 2012. T. LXI, № 1. C. 113-125.

7. Influence on matrix metalloproteinases 3,9 , and 13 levels after blocking stromal cell derived factor $1 /$ chemokine receptor 4 signaling pathway with AMD3100 / Y. Li, G. Wang, B. Cao et al. Zhongguo Xiu Fu Chong Jian Wai Ke Za Zhi. 2012. V. 26 (6). P. 652-6.

8. Expression profiling of metalloproteinases and their inhibitors in sinovium and cartilage. R. K. Davidson et al. Arthritis Research Therapy. 2006. V. 8. P. R124.

9. Differential regulation of matrix metalloproteinase 2 and matrix metalloproteinase 9 by activated protein C relevance to inflammation in rheumatoid arthritis. M. Xue et al. Arthritis Rheumatism. 2007. V. 56, № 9. P. 2864-74.

10. Металлопротеиназы 1 и 13 как маркеры деструктивно-пролиферативного процесса суставного хряща при экспериментальном остеоартрозе. С. А. Демкин, Д. А. Маланин, Л. Н. Рогова и др. Вестник ВолгГМУ. 2017. № 1 (61). С. 69-73.

11. Авдеева А. С., Александрова Е. Н., Насонов Е. Л. Клиническое значение матриксных металлопротеиназ при ревматоидном артрите (обзор литературы и собственные данные). Научнопрактическая ревматология. 2014. № 52 (1). С. 79-84.

12. Mehana E. E., Khafaga A. F., El-Blehi S. S. The role of matrix metalloproteinases in osteoarthritis pathogenesis: An updated review. Life Sci. 2019. V. 1 (234). P. 1167-86.

13. Activation of matrix metalloproteinases 2,9 , and 13 by activated protein $C$ in human osteoarthritic cartilage chondrocytes. M. T. Jackson, B. Moradi, M. M. Smith et al. Arthritis Rheumatol. 2014. V. 66 (6). P. $1525-36$.

14. Burrage P. S., Brinckerhoff C. E. Molecular targets in osteoarthritis: metalloproteinases and their inhibitors. Curr Drug Targets. 2007. V. 8 (2). P. 293-303.

15. Носивец Д. С. Экспериментальные модели патологии хрящевой ткани. Запорожский медицинский журнал. 2019. Т. 21, № 4 (115). С. 554-560. 
16. Guingamp C., Gegout-Pottie P., Philippe L. Mono-iodoacetate-induced experimental osteoarthritis: a dose-response study of loss of mobility, morphology, and biochemistry. Arthritis Rheum. 1997. V. 40 (9). P. 1670-9.

17. Argumedo G. S., Sanz C. R., Olguín H. J. Experimental models of developmental hypothyroidism. Horm Metab Res. 2012. V. 44. P. 79-85.

18. Полоз А. И., Финогенов А. Ю. Методические указания по гуманной эвтаназии животных. Минск, 2008. 45 с.

19. Руководство по проведению доклинических исследований лекарственных средств; под ред. А. Н. Миронова Ч. 1. Москва, 2012. 944 с.

20. Костюк В. О. Прикладна статистика: навч. посібник. Харків : Харківський національний університет міського господарства імені О. М. Бекетова, 2015. 191 с.

21. Matrix metalloproteinase-1, $-3,-13$ and aggrecanase- 1 and -2 are differentially expressed in experimental osteoarthritis. G. Bluteau, T. Conrozier, P. Mathieu et al. Biochim Biophys Acta. 2001. V. 3, № 1526 (2). P. 147-58.

22. Tetlow L. C., Adlam D. J., Woolley D. E. Matrix metalloproteinase and proinflammatory cytokine production by chondrocytes of human osteoarthritic cartilage: associations with degenerative changes. Arthritis Rheum. 2001. V. 44 (3). P. 585-94.

23. Young D. A., Barter M. J., Wilkinson D. J. Recent advances in understanding the regulation of metalloproteinases. F1000Res. 2019. V. 18. P. 8.

24. Burrage P. S., K. S. Mix, Brinckerhoff C. E. Matrix metalloproteinases: role in arthritis. Front Biosci. 2006. V. 1 (11). P. 529-43.

25. Турна A. А. Активность матриксных металлопротеиназ при различных патогенетических вариантах воспаления: автореф. дис. на соискание учен. степени докт. мед. наук. Москва, 2010. 50 c.

\section{Д. С. Носівець, В. Й. Мамчур, В. І. Опришко \\ Зміни вмісту металопротеїназ сироватки крові щурів під впливом нестероїдних протизапальних засобів і парацетамолу на фоні експериментального остеоартрозу та гіпотиреозу}

Одна з проблем лікування коморбідних станів пов'язана з визначенням факторів, які могли б передбачити ефективність лікування остеоартрозу на фоні гіпотиреозу. Сьогодні відомо, що одним з таких факторів $€$ визначення рівня матриксних металопротеїназ.

Мета дослідження - вивчити зміни рівня матриксних металопротеїназ 3, 9 та 13 під впливом нестероїдних протизапальних засобів та парацетамолу на фоні експериментальних еквівалентів остеоартрозу та гіпотиреозу.

Експерименти проведені на 75 білих нелінійних щурах обох статей, яким відтворений остеоартроз та гіпотиреоз. Кількісний рівень матриксних металопротеїназ сироватки крові визначали методом конкурентного імуноферментного аналізу на 42 та 47 добу експерименту.

Аналіз отриманих результатів дозволив встановити, що зміни рівня матриксних металопротеїназ у сироватці крові щурів під впливом різних нестероїдних протизапальних засобів і парацетамолу відбуваються неоднаково. На підставі проведеного дослідження встановлено, що визначення рівня матриксних металопротеїназ дозволяє оцінити протизапальну активність нестероїдних протизапальних засобів на фоні коморбідної патології - експериментальних еквівалентів остеоартрозу та гіпотиреозу. За ступенем впливу на дегенеративно-дистрофічні процеси в кістковій і хрящовій тканині досліджені препарати можна розташувати наступним чином: диклофенак натрію > ібупрофен > німесулід = мелоксикам > целекоксиб > парацетамол.

Ключові слова: остеоартроз, гіпотиреоз, , фармакотерапія, біохімічні маркери, матриксні металопротеїнази, нестероїдні протизапальні засоби

\section{Д. С. Носивец, В. И. Мамчур, В. И. Опрышко \\ Изменения содержания металлопротеиназ сыворотки крови крыс под влиянием нестероидных противовоспалительных средств и парацетамола на фоне экспериментального остеоартроза и гипотиреоза}

Одна из проблем лечения коморбидных состояний связана с определением факторов, которые могли бы предсказать эффективность лечения остеоартроза на фоне гипотиреоза. В настоящее время известно, что одним из таких факторов является уровень матриксных металлопротеиназ.

Цель исследования - изучить изменения уровня матриксных металлопротеиназ 3, 9 и 13 под влиянием нестероидных противовоспалительных средств и парацетамола на фоне экспериментальных эквивалентов остеоартроза и гипотиреоза.

Эксперименты проведены на 75 белых нелинейных крысах обоего пола, которым воссоздан остеоартроз и гипотиреоз. Количественный уровень матриксных металлопротеиназ сыворотки крови определяли методом конкурентного иммуноферментного анализа на 42 и 47 сутки эксперимента. 
При анализе полученных результатов установлено, что изменения уровня матриксных металлопротеиназ в сыворотке крови крыс под влиянием нестероидных противовоспалительных средств и парацетамола происходят неодинаково. На основании проведенного исследования установлено, что определение уровня матриксных металлопротеиназ позволяет оценить противовоспалительную активность нестероидных противовоспалительных средств на фоне экспериментальных эквивалентов остеоартроза и гипотиреоза. По степени воздействия на дегенеративно-дистрофические процессы в костной и хрящевой ткани исследованные препараты можно распределить следующим образом: диклофенак натрия > ибупрофен $>$ нимесулид $=$ мелоксикам > целекоксиб > парацетамол.

Ключевые слова: остеоартроз, гипотиреоз, фармакотерапия, биохимические маркеры, матриксные металлопротеиназы, нестероидные противовоспалительные средства

\section{S. Nosivets, V. I. Mamchur, V. I. Opryshko Changes in the level of rat blood serum metalloproteinases under influence of NSAIDs and paracetamol at experimental osteoarthritis and hypothyroidism}

One of the problems in the treatment of comorbid conditions is associated with the identification of factors that could predict the effectiveness of the treatment of osteoarthritis and hypothyroidism. It is known that one of these factors is the determination of the level of matrix metalloproteinases. It is known that hypofunction of the thyroid gland leads to metabolic disorders that negatively affect the condition of bone and cartilage, causing the development of osteoarthritis. Although NSAIDs are effective in reducing pain and inflammation in patients with osteoarthritis, but it is still unclear to what extent these drugs can affect joint metabolism and, therefore, joint structure, especially against the background of functional thyroid insufficiency.

The aim of the study - to research the changes in the level of matrix metalloproteinases 3, 9 and 13 under the influence of NSAIDs and paracetamol at experimental equivalents of osteoarthritis and hypothyroidism.

The experiments were performed on 75 white non-linear rats of both sexes with model of osteoarthritis and hypothyroidism. Experimental osteoarthritis was performed by single intra-articular administration of 0.1 $\mathrm{ml}$ of monoacetic acid solution in the knee joint ( $3 \mathrm{mg}$ of the reagent on $50 \mu \mathrm{l}$ of sterile physiological saline). Experimental hypothyroidism was modeled by enteral administration of a $0,02 \%$ solution of carbimazole, for 6 weeks. The adequacy of the model was confirmed by the level of serum TSH, T3 and T4 in rats. After the formation of the experimental models on the 42 day of the experiment, the animals were divided into 14 groups and started drug administration (NSAIDs and paracetamol) for 5 days. The quantitative level of matrix metalloproteinases in blood serum was determined by competitive in vitro ELISA twice - on 42 and 47 days of the experiment. Blood samples were obtained from the rat tail vein by puncture using a vacuum system at 42 and 47 days of the experiment. Statistical data processing was performed.

An analysis of the results found that changes in the level of matrix metalloproteinases in rat blood serum under the influence of different NSAIDs and paracetamol are not the same. Based on the study, it was found that the determination of the level of matrix metalloproteinases allows one to evaluate the antiinflammatory activity of NSAIDs under experimental equivalents of osteoarthritis and hypothyroidism. According to the degree of influence on degenerative-dystrophic processes in bone and cartilage tissue, the studied drugs can be positioned as follows: diclofenac sodium $>$ ibuprofen $>$ nimesulide $=$ meloxicam $>$ celecoxib > paracetamol.

Key words: osteoarthritis, hypothyroidism, pharmacotherapy, biochemical markers, matrix metalloproteinases, NSAIDs

\section{ORCID ID авторів:}

Носівець Д. С. (ORCID ID 0000-0001-9954-6027);

Опришко В. I. (ORCID ID 0000-0002-8369-5439).

Надійшла: 9 січня 2020 р.

Прийнята до друку: 12 лютого 2020 р.

Контактна особа: Носівець Д. С., кандидат медичних наук, кафедра фармакології та клінічної фармакології, ДЗ «Дніпропетровська медична академія МОЗУ», буд. 9, вул. Володимира Вернадського, м. Дніпро, 49044. Тел.: + 3806773991 17. Електронна пошта: dsnosivets@ukr.net 